Article

\title{
Translating Evidence-Based Guidelines into Practice-Are We Getting It Right? A Multi-Centre Prospective International Audit of Nutrition Care in Patients with Foregut Tumors (INFORM)
}

\author{
Merran Findlay $1,2, *\left(\mathbb{0}\right.$, Judith D. Bauer ${ }^{3}{ }^{\circ}$, Rupinder Dhaliwal ${ }^{4}$, \\ Marian de van der Schueren ${ }^{5,6}\left(\mathbb{D}\right.$, Alessandro Laviano ${ }^{7}{ }^{(0}$, Adrianne Widaman ${ }^{8,9}$, \\ Lisa Martin ${ }^{10}{ }^{\mathbb{D}}$, Andrew G. Day ${ }^{11}$ and Leah M. Gramlich ${ }^{12}$ \\ 1 Cancer Services, Royal Prince Alfred Hospital, Camperdown, NSW 2050, Australia \\ Chris O’Brien Lifehouse, Camperdown, NSW 2050, Australia \\ 3 School of Human Movement and Nutrition Sciences, University of Queensland, \\ St Lucia, QLD 4072, Australia; j.bauer1@uq.edu.au \\ 4 Canadian Nutrition Society, Ottawa, ON K1C 6A8, Canada; rupinder@cns-scn.ca \\ 5 Department of Nutrition, Dietetics and Lifestyle, School of Allied Health, HAN University of Applied \\ Sciences, 6503 GL Nijmegen, The Netherlands; marian.devanderschueren@han.nl \\ 6 Department of Human Nutrition and Health, Wageningen University and Research, \\ 6700 AA Wageningen, The Netherlands \\ 7 Department of Translational and Precision Medicine, Sapienza University of Rome, I-00185 Rome, Italy; \\ alessandro.laviano@uniroma1.it \\ 8 Department of Nutrition, Food Science and Packaging, San Jose State University, San Jose, CA 95192, USA; \\ adrianne.widaman@sjsu.edu \\ 9 University of California Davis Medical Center, Sacramento, CA 94558-5004, USA \\ 10 Department of Medicine, Cross Cancer Institute, University of Alberta, Edmonton, AB T6G 1Z2, Canada; \\ 1s2@ualberta.ca \\ 11 Department of Public Health Sciences, Queen's University, Kingston, ON K7L 2V7, Canada; \\ Andrew.Day@kingstonhsc.ca \\ 12 Royal Alexandra Hospital, Division of Gastroenterology, Department of Medicine, University of Alberta, \\ Edmonton, AB T5H 3V9, Canada; lg3@ualberta.ca \\ * Correspondence: merran.findlay@health.nsw.gov.au; Tel.: +61-(0)411-779-420
}

Received: 29 October 2020; Accepted: 8 December 2020; Published: 11 December 2020

\begin{abstract}
Malnutrition is highly prevalent in patients with foregut tumors comprising head and neck (HNC) and esophageal (EC) cancers, negatively impacting outcomes. International evidence-based guidelines (EBGs) for nutrition care exist; however, translation of research evidence into practice commonly presents considerable challenges and consequently lags. This study aimed to describe and evaluate current international nutrition care practices compared with the best-available evidence for patients with foregut tumors who are at high risk of malnutrition. A multi-centre prospective cohort study enrolled 170 patients commencing treatment of curative intent for HNC $(n=119)$ or EC $(n=51)$ in 11 cancer care settings in North America, Europe and Australia between 2016 and 2018. Adherence criteria were derived from relevant EBG recommendations with pooled results for participating centres reported according to the Nutrition Care Model at either system or patient levels. Adherence to EBG recommendations was: good $(\geq 80 \%)$ for performing baseline nutrition screening and assessment, perioperative nutrition assessment and nutrition prescription for energy and protein targets; moderate ( $\geq 60$ to $<80 \%$ ) for utilizing validated screening and assessment tools and pre-radiotherapy dietitian consultation; and poor $(<60 \%)$ for initiating post-operative nutrition support within $24 \mathrm{~h}$ and also dietetic consultation weekly during radiotherapy and fortnightly for 6 weeks post-radiotherapy. In conclusion, gaps in evidence-based cancer nutrition care remain; however, this may be improved by filling known evidence gaps through high-quality research with a concurrent evolution of EBGs to
\end{abstract}


also encompass practical implementation guidance. These should aim to support multidisciplinary cancer clinicians to close evidence-practice gaps throughout the patient care trajectory with clearly defined roles and responsibilities that also address patient-reported concerns.

Keywords: head and neck cancer; esophageal cancer; malnutrition; implementation; evidence-based practice; research translation

\section{Introduction}

Malnutrition is highly prevalent in patients with foregut tumors comprising head and neck (HNC) and esophageal (EC) cancers with rates commonly reported between 30 and $80 \%$ [1-3]. Characterized by a negative energy balance and skeletal muscle depletion, cancer-associated malnutrition is driven by a combination of reduced food intake and deranged metabolism [4]. Its etiology in patients with foregut tumors is complex, arising from factors related to: diagnosis (tumor location contributing to mechanical obstruction and tumor-induced metabolic derangements, cachexia and skeletal muscle catabolism); a prolonged, multi-modal treatment trajectory (surgery, radiotherapy and/or systemic therapy-related extensive nutrition-impact symptoms and treatment toxicities); and patient-related factors (age, pre-morbid nutritional status, socioeconomic circumstances and lifestyle factors such as alcohol and tobacco use) [5-7]. Patients can present as well-nourished at diagnosis, yet, due to the considerable disease and treatment burden, still develop the detrimental sequelae of malnutrition irrespective of overall weight status.

The best-available evidence to guide cancer nutrition care in practice has been synthesized in international evidence-based guidelines (EBGs) from Australia [8,9], Europe [10-14], North America [15] and the United Kingdom [16] (Table 1), demonstrating that optimizing nutrition care delivery leads to a positive impact on clinical, cost and patient-centred outcomes. These EBGs encompass nutrition care recommendations for varying aspects of the patient care trajectory and offer a focused synthesis by tumor site such as HNC $[8,10,16]$ treatment modalities including radiotherapy and chemotherapy [9] and surgery [10-13] or cancer nutrition care [14,15] more broadly. A range of literature synthesis and quality appraisal methods [17-21] were employed in the development of the various EBGs; however, key recommendations are consistent. Despite the existence of EBGs, uptake of guidelines and translation of research evidence into practice lags up to 17 years in healthcare settings [22-26].

Underpinning quality nutrition care is the widely recognised Nutrition Care Model $[27,28]$, comprising three domains: (1) Appropriate Access to Care (Nutrition Screening and Nutrition Assessment); (2) Quality Nutrition Care (Goals, Prescription, Implementation); and (3) Nutrition Evaluation and Monitoring (Measure and Evaluate Outcomes). Figure 1 depicts typical oncological treatment trajectories for patients with foregut tumors aligned with the Nutrition Care Model. In the first domain, elements of evidence-based nutrition care processes encompass use of validated tools for malnutrition screening and nutrition assessment such as the Subjective Global Assessment (SGA) [29] or Patient-Generated Subjective Global Assessment (PG-SGA) [30] specifically designed for use in oncology populations. Like the PG-SGA, the PG-SGA Short Form (PG-SGA SF) utilizes a patient-centric approach through self-identification of issues that impact nutrition yet still covers the conceptual domains of malnutrition and can therefore be used as a valid and reliable screening and monitoring instrument [31]. Patients with highly complex care needs require early and frequent access to dietitians with expertise in nutrition support; however, dietetic workforce resources in the cancer care setting are often inadequate [32-34].The second domain Quality Nutrition Care focuses on nutrition care processes around the timing and frequency of dietetic interventions, nutrition prescription, e.g., energy and protein and implementation such as commencing nutrition support, e.g., tube feeding. In the third domain, Measure and Evaluate Outcomes, EBGs seek to make recommendations regarding timing and 
frequency of dietetic interventions throughout the treatment trajectory and key nutrition elements and outcomes that should be monitored, e.g., weight, intake and nutritional status.

Table 1. Evidence-based clinical practice guidelines for nutritional management of adults with cancer.

\begin{tabular}{|c|c|c|c|c|}
\hline First Author, Year & Origin & Organisation & $\begin{array}{l}\text { Guideline } \\
\text { Focus }\end{array}$ & $\begin{array}{l}\text { Appraisal } \\
\text { Method }\end{array}$ \\
\hline Arends, 2017 [14] & Europe & ESPEN $^{a}$ & Cancer & GRADE $^{b}$ \\
\hline Dort, 2017 [10] & International & ERAS ${ }^{\mathrm{c}}$ Society & Surgery-HNC ${ }^{\mathrm{d}}$ & GRADE \\
\hline Thompson, 2017 [15] & USA $^{\mathrm{e}}$ & AND $^{f}$ & Cancer & AND EAL $\mathrm{g}$ \\
\hline Weimann, 2017 [11] & Europe & ESPEN & Surgery & $\mathrm{SIGN}^{h}, \mathrm{AHCPR}^{\mathrm{i}}$ \\
\hline Talwar, 2016 [16] & $\mathrm{UK}^{\mathrm{j}}$ & BAHNO $^{k}$ & HNC & $\mathrm{ns}^{1}$ \\
\hline Isenring, 2013 [9] & Australia & $\mathrm{DAA}^{\mathrm{m}}$ & $\mathrm{RT}^{\mathrm{n}}, \mathrm{CTx}^{\mathrm{o}}$ & NHMRC $\mathrm{P}$ \\
\hline Findlay, 2011 [8] & Australia * & $\cos A q$ & $\mathrm{HNC}$ & NHMRC \\
\hline Braga, 2009 [12] ** & Europe & ESPEN & Surgery-PN ${ }^{\mathrm{r}}$ & ns \\
\hline Weimann, 2006 [13] ** & Europe & ESPEN & Surgery & ESPEN \\
\hline
\end{tabular}

${ }^{\mathrm{a}}$ ESPEN $=$ European Society for Clinical Nutrition and Metabolism; ${ }^{\mathrm{b}}$ GRADE $=$ Grading of Recommendations Assessment Development and Evaluation; ${ }^{\mathrm{c}}$ ERAS $=$ Enhanced Recovery After Surgery; ${ }^{\mathrm{d}} \mathrm{HNC}=$ Head and Neck Cancer; ${ }^{\mathrm{e}}$ USA $=$ United States of America; ${ }^{\mathrm{f}}$ AND $=$ American Academy of Nutrition and Dietetics; ${ }^{\mathrm{g}}$ EAL $=$ Evidence Analysis Library; ${ }^{\mathrm{h}}$ SIGN $=$ Scottish Intercollegiate Guidelines Network; ${ }^{\mathrm{i}}$ AHCPR $=$ Agency for Health Care Policy and Research; ${ }^{j}$ UK $=$ United Kingdom; ${ }^{k}$ BAHNO = British Association of Head and Neck Oncologists; ${ }^{1} \mathrm{~ns}=$ not specified; ${ }^{\mathrm{m}} \mathrm{DAA}=$ Dietitians Association of Australia; ${ }^{\mathrm{n}} \mathrm{RT}=$ Radiotherapy $;{ }^{\circ} \mathrm{CTx}=$ Chemotherapy; p NHMRC $=$ National Health and Medical Research Council; ${ }^{q}$ COSA $=$ Clinical Oncology Society of Australia; ${ }^{\mathrm{r}}$ PN = Parenteral Nutrition; * Endorsed by Dietitians Association of Australia, Dietitians New Zealand, British Dietetics Association and available via Dietitians Canada Practice-Based Evidence in Nutrition online portal; ** Merged into Weimann et al., 2017 [11].

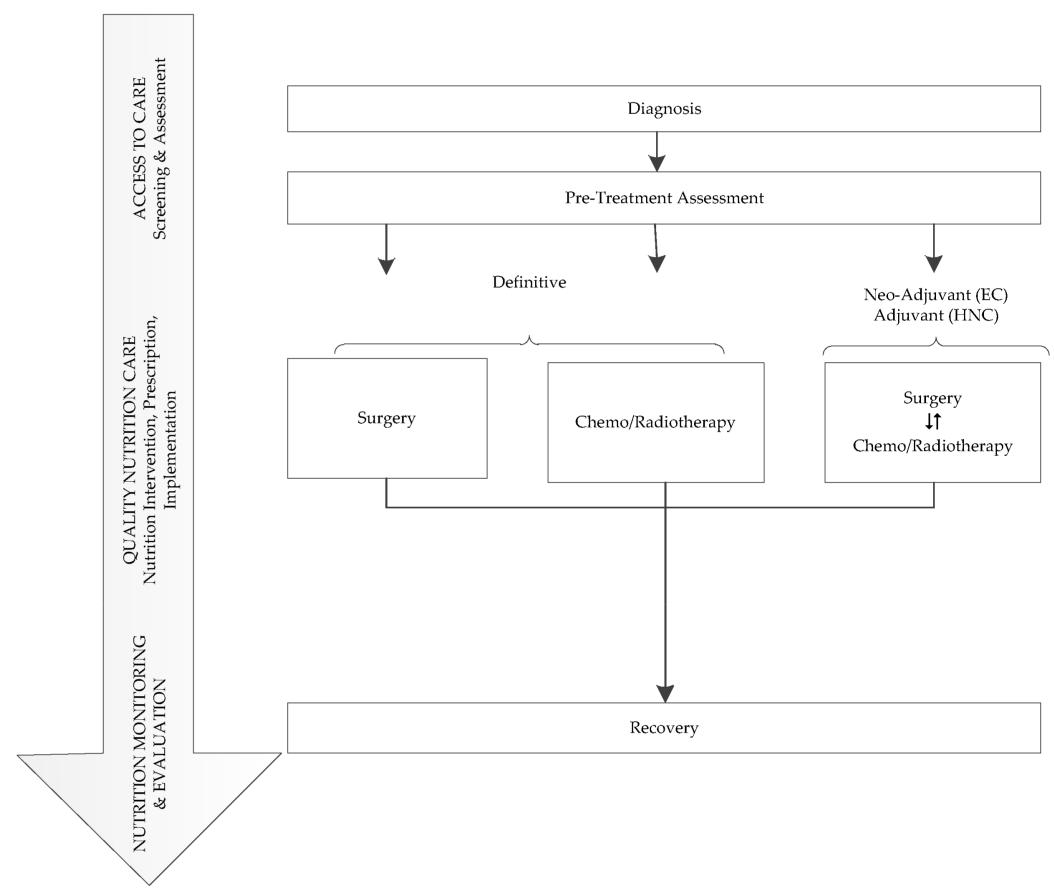

Figure 1. Overview of oncological treatment for patients with foregut tumors aligned with the Nutrition Care Model $[27,28]$.

Successful implementation of research evidence into clinical practice requires identification of barriers to change and facilitators to overcome them in order for potential benefits of EBGs to be realized [35]. A Canadian-led international qualitative study exploring the barriers and enablers to nutrition care of patients with foregut tumors identified, firstly, a need to improve the evidence base and, secondly, to establish a minimum data set with a view to developing standardized nutrition care pathways with defined roles and responsibilities [36]. Recent Australian-led studies demonstrated that the multi-strategic implementation of innovative models of care increased adherence to EBGs 
for nutritional management of patients with HNC [8] resulted in improvements in nutritional status, quality of life [37], treatment completion, unplanned hospital admissions and associated costs of care [38]. This study aimed to (i) describe and evaluate current international nutrition care practices compared with the best-available evidence from published EBGs for patients with foregut tumors at high risk of malnutrition and (ii) determine any critical points where evidence-practice gaps persist and identify opportunities for improvement in nutrition care processes.

\section{Materials and Methods}

\subsection{Study Design, Setting and Population}

The International audit of Nutrition care in patients with FORegut tuMors (INFORM) multi-centre prospective cohort study was undertaken at 11 cancer care settings in Canada ( $n=6$ from two cities), Australia $(n=2)$, Italy $(n=1)$, the Netherlands $(n=1)$ and the United States of America (USA), $(n=1)$ between 2016 and 2018. Participating sites were teaching hospitals required to have a registered dietitian, clinical nutritionist or nutrition delegate available for study co-ordination. Inclusion criteria were adult ( $\geq 18$ years) patients with a diagnosis of HNC or EC commencing treatment (any modality) of curative intent. Exclusion criteria were either absence of a treatment plan due to imminent death or an Eastern Co-operative Oncology Group (ECOG) [39] score $\geq 4$.

\subsection{Outcomes}

The primary outcome was adherence to EBG nutrition care recommendations throughout the treatment trajectory for which adherence criteria based on international EBGs are presented in Table 2. Data regarding Appropriate Access to Care (Nutrition Screening and Assessment) are reported per usual practice at each site at the time of study enrollment and are therefore referred to here as system level outcomes within participating centres. The remainder of the adherence criteria are reported as a proportion of included patients and by participating site. The optimum degree of adherence to EBGs has not been determined; however, adherence rates of $80 \%$ to set criteria has been proposed [14] and applied in recent studies [37,38]. In this study, adherence to EBG recommendations was categorized as good $(\geq 80 \%)$, moderate $(\geq 60$ to $<80 \%)$ and poor $(<60 \%)$.

At study enrollment, each site provided cancer care setting demographics and details regarding which nutrition care processes were already established as part of standard care. Nutrition screening was defined as the process to identify an individual who is either malnourished or at risk of malnutrition to determine if a detailed nutrition assessment is indicated. Each study site reported their baseline practices regarding the validated tool or criteria used to identify patients who were malnourished or at risk of malnutrition. The validated tools for nutrition screening used in participating sites included the Malnutrition Screening Tool (MST) [40], Nutrition Risk Screening 2002 [41], Mini Nutrition Assessment-Short Form (MNA-SF) [42] and the Short Nutritional Assessment Questionnaire (SNAQ) [43]. Due to the variability in the types of tools that were used, the study protocol required participating sites to adopt the PG-SGA SF as the screening tool to facilitate longitudinal comparisons in nutrition risk across sites. To avoid misinterpretation of adherence data related to screening processes initiated as part of the study protocol (PG-SGA SF), each study site's reported baseline practices were considered to be reflective of nutrition care processes with regards to screening and assessment. Nutrition assessment was defined as a comprehensive approach to diagnosing nutrition problems that use a combination of medical, nutrition, medication histories, physical examination, anthropometric measurements and laboratory data. Validated tools for comprehensive nutritional assessment for the purpose of evaluating nutritional status and, in particular, diagnosing the degree of malnutrition, if present, comprised both the PG-SGA [30] and SGA [29]. In this study, the criteria for comprehensive assessment of nutritional status was not considered to have been met where measures used in isolation, e.g., anthropometry alone were not assimilated as part of a comprehensive evaluation of nutritional status as outlined above. 
Table 2. Adherence criteria for evidence-based guideline recommendations.

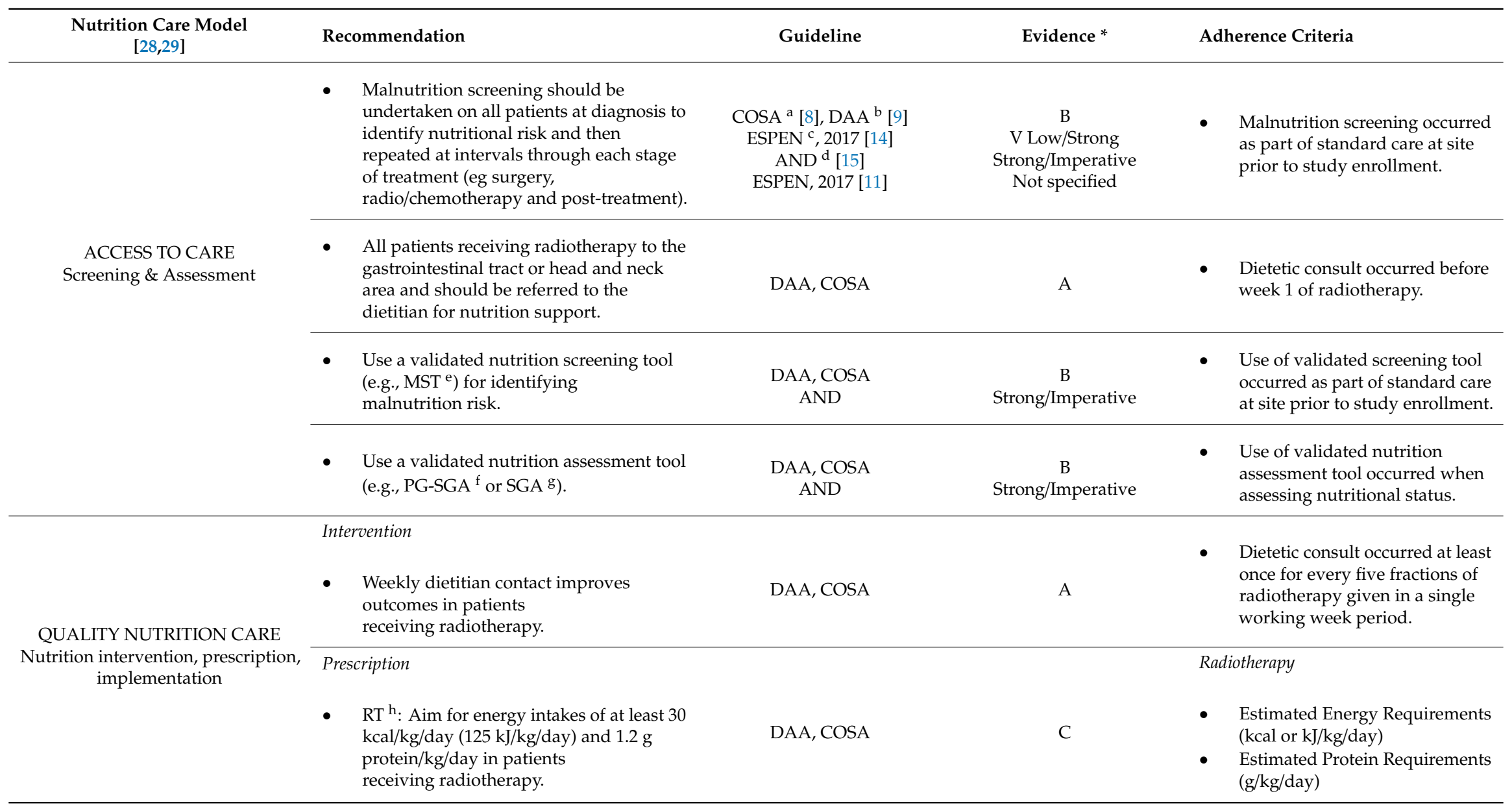


Table 2. Cont

\begin{tabular}{|c|c|c|c|c|}
\hline $\begin{array}{l}\text { Nutrition Care Model } \\
{[28,29]}\end{array}$ & Recommendation & Guideline & Evidence * & Adherence Criteria \\
\hline & \multirow{4}{*}{$\begin{array}{l}\text { - Surgery: Aim for Energy intakes of at } \\
\text { least } 30 \mathrm{kcal} / \mathrm{kg} / \text { day }(125 \mathrm{~kJ} / \mathrm{kg} / \text { day }) / 25-30 \\
\text { kcal } / \mathrm{kg} \mathrm{IBW} \text { I } / \text { day. } \\
\text { - Protein intake of } 1.5 \mathrm{~g} / \mathrm{kg} \mathrm{IBW} \mathrm{in} \\
\text { illness } / \text { stress. }\end{array}$} & \multirow{4}{*}{$\begin{array}{l}\text { COSA } \\
\text { ESPEN 2017 [14] } \\
\text { ESPEN 2009 [12] } \\
\text { ESPEN 2009 [12] }\end{array}$} & \multicolumn{2}{|r|}{ Surgery } \\
\hline & & & & \\
\hline & & & B & (kcal or kJ/kg/day) \\
\hline & & & B & $\begin{array}{l}\text { - Estimated Protein Requirements } \\
(\mathrm{g} / \mathrm{kg} / \text { day })\end{array}$ \\
\hline & \multicolumn{4}{|l|}{ Implementation } \\
\hline & $\begin{array}{l}\text { - Surgery: Post-operative tube feeding } \\
\text { should commence within } 24 \mathrm{~h} \text {. }\end{array}$ & $\begin{array}{c}\text { ERAS }^{j}[10] \\
\text { ESPEN } 2017[11]\end{array}$ & $\begin{array}{l}\text { Mod/Strong } \\
\text { A/GPP k }\end{array}$ & commenced within $24 \mathrm{~h}$. \\
\hline \multirow[b]{2}{*}{$\begin{array}{l}\text { NUTRITION MONITORING \& } \\
\text { EVALUATION }\end{array}$} & $\begin{array}{l}\text { Patients should be seen weekly by a } \\
\text { dietitian during radiotherapy. }\end{array}$ & DAA, COSA & A & - $\quad$ As above \\
\hline & $\begin{array}{l}\text { Patients should receive minimum } \\
\text { fortnightly follow up by a dietitian for at } \\
\text { least } 6 \text { weeks post radiotherapy. }\end{array}$ & DAA, COSA & A & $\begin{array}{l}\text { - Dietetic consult occurred at least } \\
\text { once in a } 14 \text { day period } \\
\text { following end of radiotherapy } \\
\text { for three consecutive fortnights. }\end{array}$ \\
\hline
\end{tabular}


Nutrition diagnosis is described as a critical step in the nutrition care model between assessment and intervention involving the identification and labeling of the specific nutrition problems that dietetics professionals are responsible for treating [44]. Examples of nutrition diagnoses include malnutrition (undernutrition), unintended weight loss, increased nutrient needs, inadequate protein-energy intake although there are many potential diagnoses that could be applied to the patient population studied here. Secondary outcomes were the impact of adherence to EBG recommendations on treatment completion and unplanned hospital admissions.

\subsection{Data Collection}

Research Electronic Data Capture (REDCap) [45] hosted at the University of Alberta, Canada, was used to capture data collected at each participating site from electronic and paper-based electronic medical records.

\subsection{Statistical Analysis}

All results are presented using descriptive statistics. Categorical variables are described as counts and percentages while continuous variables are described as medians and quartiles. All analysis was completed using SAS Version 9.4 (SAS Institute Inc., Cary, NC, USA).

\subsection{Ethics Approval and Reporting}

For Canadian locations as the international lead-site, ethics approval was obtained (HREBA.CC-15-0238). All other participating sites obtained ethics approval from their local ethics committee with Site-Specific Approval obtained for each of the participating sites, and patient consent was obtained. The study is reported according to the Strengthening the Reporting of Observational Studies in the Epidemiology (STROBE) checklist [46].

\section{Results}

\subsection{Baseline Characteristics}

Baseline patient, diagnosis and treatment characteristics are presented in Table 3. A total of 170 patients, with a diagnosis of either HNC $(70.0 \%)$ or EC $(30.0 \%)$ were recruited from 11 international sites. Patients were predominantly male (78.8\%), Caucasian (94.7\%) with a median [Q1, Q3] age of 62 [58, 69] years and an ECOG performance status $\leq 1(92.8 \%)$. Tumor type was most commonly adenocarcinoma $(80.4 \%)$ for patients with oesophageal cancer and the three most common tumor sites for HNC were oropharynx (32.8\%), oral cavity $(26.9 \%)$ and larynx $(18.5 \%)$. Patients with HNC were more likely to have advanced clinical stage (III/IV) than patients with EC (77.4\% versus 37.3\%). Most patients $(74.2 \%)$ received combined modality treatment in either adjuvant, neoadjuvant or definitive settings.

Baseline nutritional characteristics (Table 4) were similar for patients with either HNC or EC for both median (range) body mass index (BMI) kg/m² (26 (14-42) versus 27 (17-39)) and nutritional risk as determined by median (range) PG-SGA SF score (7 (0-29) versus 7 (0-28)). A nutrition diagnosis was made for $50 \%$ of patients, with missing data (33.5\%) likely reflective that formalizing this is not a universal practice amongst dietitians globally. The proportion of patients requiring nutrition support in terms of tube feeding during treatment was high for patients receiving surgery $(70.3 \%)$ and radiotherapy $(62.7 \%)$. 
Table 3. Baseline characteristics.

\begin{tabular}{|c|c|c|c|}
\hline Characteristic & $\begin{array}{l}\text { Head and Neck } \\
\qquad \begin{array}{c}(n=119) \\
n(\%)\end{array}\end{array}$ & $\begin{array}{c}\text { Esophageal } \\
\quad(n=51) \\
n(\%)\end{array}$ & $\begin{array}{c}\text { All } \\
(n=170) \\
n(\%)\end{array}$ \\
\hline \multicolumn{4}{|l|}{ Centre (Country-City) } \\
\hline Australia-Brisbane & $10(8.4 \%)$ & $0(0.0 \%)$ & $10(5.9 \%)$ \\
\hline Australia-Sydney & $20(16.8 \%)$ & $0(0.0 \%)$ & $20(11.8 \%)$ \\
\hline Canada-Calgary * & $21(17.6 \%)$ & $10(19.6 \%)$ & $31(18.2 \%)$ \\
\hline Canada-Edmonton * & $20(16.8 \%)$ & $18(35.3 \%)$ & $38(22.4 \%)$ \\
\hline Italy-Rome & $19(16.0 \%)$ & $0(0.0 \%)$ & $19(11.2 \%)$ \\
\hline Netherlands-Amsterdam & $20(16.8 \%)$ & $23(45.1 \%)$ & $43(25.3 \%)$ \\
\hline USA-Sacramento & $9(7.6 \%)$ & $0(0.0 \%)$ & $9(5.3 \%)$ \\
\hline \multicolumn{4}{|l|}{ Age, years } \\
\hline \multicolumn{4}{|l|}{ Sex } \\
\hline Male & $93(78.2 \%)$ & $41(80.4 \%)$ & $134(78.8 \%)$ \\
\hline Female & $26(21.8 \%)$ & $10(19.6 \%)$ & $36(21.2 \%)$ \\
\hline \multicolumn{4}{|l|}{ Ethnicity } \\
\hline Caucasian & $111(93.3 \%)$ & $50(98.0 \%)$ & $161(94.7 \%)$ \\
\hline First Nations & $1(0.8 \%)$ & $0(0.0 \%)$ & $1(0.6 \%)$ \\
\hline Hispanic & $2(1.7 \%)$ & $0(0.0 \%)$ & $2(1.2 \%)$ \\
\hline Asian & $3(2.5 \%)$ & $1(2.0 \%)$ & $4(2.4 \%)$ \\
\hline East Indian & $1(0.8 \%)$ & $0(0.0 \%)$ & $1(0.6 \%)$ \\
\hline Other & $1(0.8 \%)$ & $0(0.0 \%)$ & $1(0.6 \%)$ \\
\hline \multicolumn{4}{|l|}{ Current Smoker } \\
\hline Yes & $44(37.0 \%)$ & $13(25.5 \%)$ & $57(33.5 \%)$ \\
\hline No & $75(63.0 \%)$ & $38(74.5 \%)$ & $113(66.5 \%)$ \\
\hline \multicolumn{4}{|l|}{ Alcohol use } \\
\hline Yes & $47(39.5 \%)$ & $9(17.6 \%)$ & $56(32.9 \%)$ \\
\hline No & $72(60.5 \%)$ & $42(82.4 \%)$ & $114(67.1 \%)$ \\
\hline \multicolumn{4}{|l|}{ ECOG $^{\text {a }}$ Performance Status } \\
\hline 0 & $78(65.5 \%)$ & $32(62.7 \%)$ & $110(64.7 \%)$ \\
\hline 1 & $32(26.9 \%)$ & $16(31.4 \%)$ & $48(28.2 \%)$ \\
\hline 2 & $6(5.0 \%)$ & $3(5.9 \%)$ & $9(5.3 \%)$ \\
\hline 3 & $3(2.5 \%)$ & $0(0.0 \%)$ & $3(1.8 \%)$ \\
\hline \multicolumn{4}{|l|}{ Clinical Stage } \\
\hline 1 & $5(4.2 \%)$ & $4(7.8 \%)$ & $9(5.3 \%)$ \\
\hline 2 & $8(6.7 \%)$ & $13(25.5 \%)$ & $21(12.4 \%)$ \\
\hline 3 & $18(15.1 \%)$ & $15(29.4 \%)$ & $33(19.4 \%)$ \\
\hline 4 (Any) & $74(62.2 \%)$ & $4(7.8 \%)$ & $78(45.9 \%)$ \\
\hline Could not assess stage & $7(5.9 \%)$ & $11(21.6 \%)$ & $16(10.6 \%)$ \\
\hline Not staged & $7(5.9 \%)$ & $4(7.8 \%)$ & $11(6.5 \%)$ \\
\hline \multicolumn{4}{|l|}{ Tumor Site-Head and Neck } \\
\hline Primary unknown & $3(2.5 \%)$ & & $3(1.8 \%)$ \\
\hline Hypopharynx & $10(8.4 \%)$ & & $10(5.9 \%)$ \\
\hline Larynx & $22(18.5 \%)$ & & $22(12.9 \%)$ \\
\hline Nasopharynx & $5(4.2 \%)$ & & $5(2.9 \%)$ \\
\hline Oral cavity & $32(26.9 \%)$ & & $32(18.8 \%)$ \\
\hline Oropharynx & $39(32.8 \%)$ & & $39(22.9 \%)$ \\
\hline Other & $3(2.5 \%)$ & & $3(1.8 \%)$ \\
\hline Salivary gland & $5(4.2 \%)$ & & $5(2.9 \%)$ \\
\hline
\end{tabular}


Table 3. Cont.

\begin{tabular}{|c|c|c|c|}
\hline Characteristic & $\begin{array}{c}\text { Head and Neck } \\
(n=119) \\
n(\%)\end{array}$ & $\begin{array}{l}\text { Esophageal } \\
\quad(n=51) \\
n(\%)\end{array}$ & $\begin{array}{c}\text { All } \\
(n=170) \\
n(\%)\end{array}$ \\
\hline \multicolumn{4}{|l|}{ Treatment Modality $\mathrm{b}$} \\
\hline None & $5(5.0 \%)$ & $5(9.8 \%)$ & $10(6.6 \%)$ \\
\hline Chemotherapy-definitive & $0(0.0 \%)$ & $2(3.9 \%)$ & $2(1.3 \%)$ \\
\hline Chemotherapy-adjuvant & $0(0.0 \%)$ & $1(2.0 \%)$ & $1(0.7 \%)$ \\
\hline Radiotherapy-definitive & $15(15.0 \%)$ & $0(0.0 \%)$ & $15(9.9 \%)$ \\
\hline Surgery & $10(10.0 \%)$ & $2(3.9 \%)$ & $12(7.9 \%)$ \\
\hline Chemoradiotherapy-definitive & $54(54.0 \%)$ & $6(11.8 \%)$ & $60(39.7 \%)$ \\
\hline Surgery $+\operatorname{adj}^{c} /$ neoadj $^{d} R^{e}$ & $7(7.0 \%)$ & $0(0.0 \%)$ & $7(4.6 \%)$ \\
\hline Surgery + adj/neoadj CRT ${ }^{f}$ & $9(9.0 \%)$ & $35(68.6 \%)$ & $44(29.1 \%)$ \\
\hline
\end{tabular}

* 3 participating sites each from Edmonton and Calgary. ${ }^{\mathrm{a}}$ ECOG $=$ European Co-Operative Group; ${ }^{\mathrm{b}}$ Treatment modality-19 patients from one site (Rome, Italy) excluded because cancer treatment was not captured; ${ }^{\mathrm{c}}$ adj $=$ adjuvant; ${ }^{\mathrm{d}}$ neoadj $=$ neoadjuvant; ${ }^{\mathrm{e}} \mathrm{RT}=$ Radiotherapy; ${ }^{\mathrm{f}} \mathrm{CRT}=$ Chemoradiotherapy.

Table 4. Baseline nutritional characteristics.

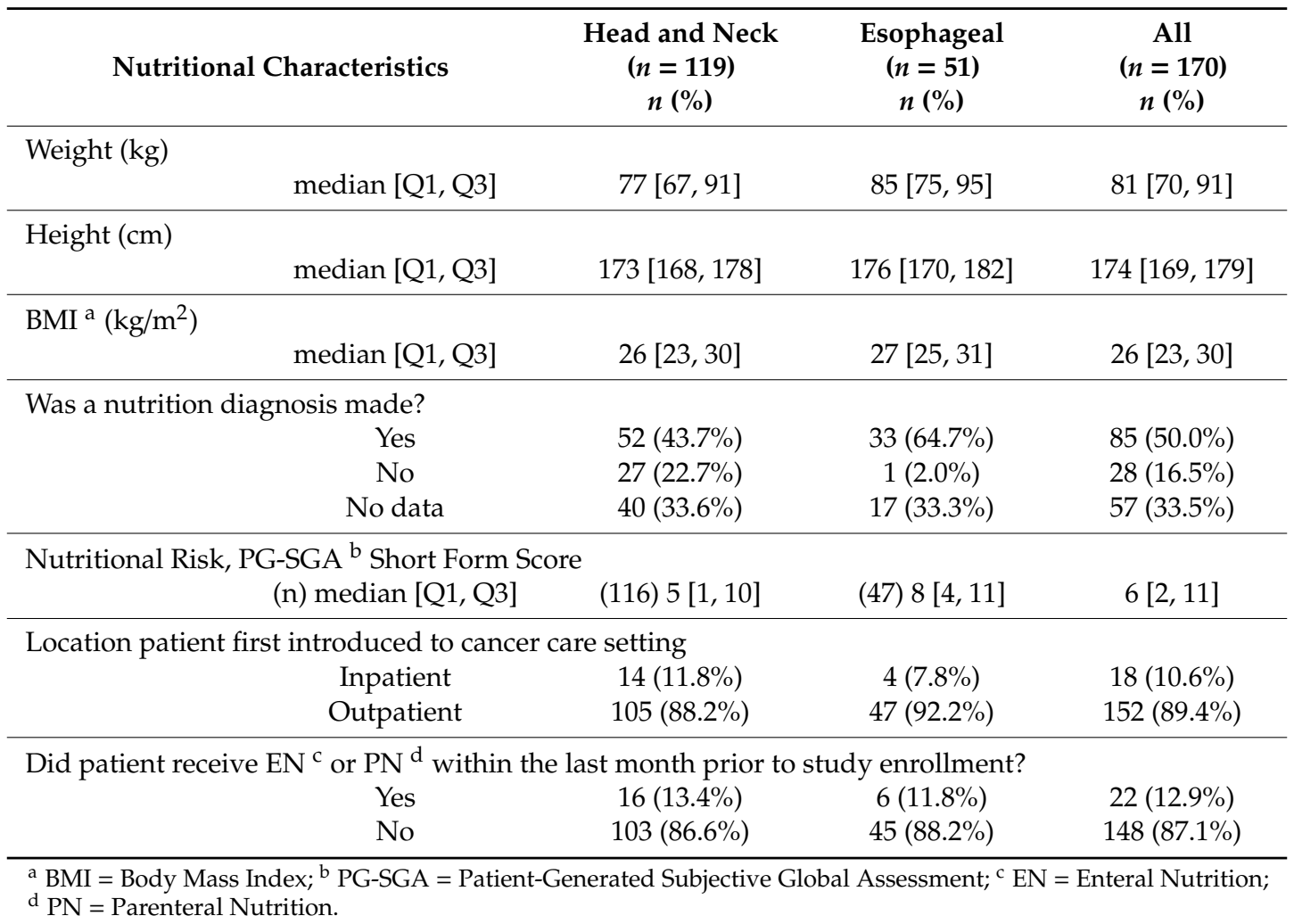

\subsection{Adherence to Evidence-Based Guideline Recommendations}

Adherence to EBG recommendations is presented in Table 5. For the first domain comprising Access to Care (Screening and Assessment), baseline nutrition care practices are as reported by each participating site. While malnutrition screening and nutrition assessment were reported to be routinely performed, validated tools were implemented for nutrition screening in $7 / 11(64 \%)$ and for nutrition assessment in $8 / 11(73 \%)$ of centres. 
Table 5. Adherence to evidence-based guideline recommendations. Access to care (screening and assessment) by the total number of participating sites $(n=11)$; quality nutrition care and nutrition monitoring and evaluation by the total number of patients $(n=170)$.

\begin{tabular}{|c|c|c|c|c|c|}
\hline $\begin{array}{l}\text { Nutrition Care } \\
\text { Model } \\
{[27,28]}\end{array}$ & $\begin{array}{c}\text { Measure-System Level } \\
\text { (Usual Practice in Centre at Study } \\
\text { Enrollment) }\end{array}$ & \multicolumn{2}{|c|}{$\begin{array}{c}\mathrm{N} \\
(n=11)\end{array}$} & \multicolumn{2}{|c|}{$\%$} \\
\hline \multicolumn{6}{|c|}{ Screening } \\
\hline \multirow{5}{*}{ Access to Care } & $\begin{array}{l}\text { Malnutrition screening routinely } \\
\text { performed. }\end{array}$ & \multicolumn{2}{|c|}{11} & \multicolumn{2}{|c|}{$100 \%$} \\
\hline & Validated nutrition screening tool used. & \multicolumn{2}{|c|}{7} & \multicolumn{2}{|c|}{$64 \%$} \\
\hline & \multicolumn{5}{|l|}{ Assessment } \\
\hline & $\begin{array}{l}\text { Nutrition assessment routinely } \\
\text { performed. }\end{array}$ & \multicolumn{2}{|c|}{11} & \multicolumn{2}{|c|}{$100 \%$} \\
\hline & Validated nutrition assessment tool used. & \multicolumn{2}{|c|}{8} & \multicolumn{2}{|c|}{$73 \%$} \\
\hline \multirow{9}{*}{$\begin{array}{l}\text { Quality Nutrition } \\
\text { Care }\end{array}$} & Measure-Patient Level & & & & \\
\hline & \multirow{2}{*}{ Surgery } & \multicolumn{2}{|c|}{$(n=26)$} & \multicolumn{2}{|c|}{$(n=38)$} \\
\hline & & $n$ & $\%$ & $n$ & $\%$ \\
\hline & $\begin{array}{l}\text { Nutrition assessment } \\
\text { Pre-operative } \\
\text { Post-operative }\end{array}$ & $\begin{array}{c}6 \\
24 \\
\end{array}$ & $\begin{array}{l}23 \% \\
92 \% \\
\end{array}$ & $\begin{array}{l}37 \\
36\end{array}$ & $\begin{array}{l}97 \% \\
95 \% \\
\end{array}$ \\
\hline & $\begin{array}{c}\text { Nutrition support-tube feeding } \\
\text { commenced } \\
\text { Pre-operative } \\
\text { Post-operative } \\
\text { within } 24 \mathrm{~h} \\
\text { within } 1 \text { to } 7 \text { days }\end{array}$ & $\begin{array}{c}1 \\
5 \\
5 \\
12\end{array}$ & $\begin{array}{l}19 \% \\
46 \%\end{array}$ & $\begin{array}{c}2 \\
17\end{array}$ & $\begin{array}{c}21 \% \\
5 \% \\
44 \%\end{array}$ \\
\hline & $\begin{array}{c}\text { Nutrition prescription, median }[\mathrm{Q} 1, \mathrm{Q} 3] \\
\text { Energy prescription }(\mathrm{kcal} / \mathrm{kg} / \mathrm{d}) \\
\text { Protein prescription }(\mathrm{g} / \mathrm{kg} / \mathrm{d})\end{array}$ & \multicolumn{2}{|c|}{$\begin{array}{c}30.8[29.6,32.7] \\
1.3[1.2,1.5]\end{array}$} & \multicolumn{2}{|c|}{$\begin{array}{c}26.3[23.2,28.1] \\
\quad 1.4[1.2,1.5]\end{array}$} \\
\hline & \multirow{2}{*}{ Radiotherapy/Chemoradiotherapy } & \multicolumn{2}{|c|}{$(n=85)$} & \multicolumn{2}{|c|}{$(n=41)$} \\
\hline & & $n^{\#}$ & $\%$ & $n^{\#}$ & $\%$ \\
\hline & $\begin{array}{c}\text { Nutrition prescription, median [Q1, Q3] } \\
\text { Energy prescription }(\mathrm{kcal} / \mathrm{kg} / \mathrm{d}) \\
\text { Protein prescription }(\mathrm{g} / \mathrm{kg} / \mathrm{d})\end{array}$ & $\begin{array}{r}30.4[2 \\
1.3[1\end{array}$ & $\begin{array}{l}, 33.4] \\
1.5]\end{array}$ & $\begin{array}{r}26.7[2 \\
1.4[\end{array}$ & $\begin{array}{l}28.8] \\
1.5]\end{array}$ \\
\hline $\begin{array}{l}\text { Nutrition } \\
\text { Monitoring and } \\
\text { Evaluation }\end{array}$ & $\begin{array}{l}\text { Received recommended dietitian } \\
\text { consultation: } \\
\text { Pre-treatment (Access to Care) } \\
\text { Weekly during treatment } \\
\text { Fortnightly for } 6 \text { weeks post-treatment }\end{array}$ & $\begin{array}{l}54 / 85 \\
36 / 85 \\
11 / 85\end{array}$ & $\begin{array}{l}64 \% \\
42 \% \\
13 \%\end{array}$ & $\begin{array}{l}27 / 41 \\
10 / 41 \\
17 / 41\end{array}$ & $\begin{array}{l}66 \% \\
24 \% \\
17 \%\end{array}$ \\
\hline
\end{tabular}

For the second and third domains of Quality Nutrition Care and Nutrition Monitoring and Evaluation, almost all patients undergoing treatment received nutrition assessment at some point during their care trajectory within the study period for either HNC (116/119, 98\%) or EC (50/51, 98\%). For patients undergoing surgery, nutrition assessment for patients with HNC was less frequent in the pre-operative setting 6/26 (23\%) and more common in the post-operative setting $24 / 26(92 \%)$ whereas, for patients with EC, nutrition assessment was high in both pre- and post-operative settings $(37 / 38,97 \%$ and $36 / 38,95 \%)$. For patients undergoing either adjuvant or definitive radiotherapy or chemoradiotherapy, pre-treatment nutrition assessment occurred for 54/85 (64\%) of patients with HNC and 27/41 (66\%) of patients with EC. The proportion of patients receiving dietitian consultation 
each week during radiotherapy (RT) ranged from $69 \%$ to $88 \%$ for patients with HNC and $41 \%$ to $74 \%$ for patients with EC. The proportion of patients that received all recommended weekly dietitian assessments prescribed by evidence-based guidelines was 36/85 (42\%) and 10/41 (24\%) for patients with HNC and EC respectively. Nutrition prescription for energy $(\mathrm{kcal} / \mathrm{kg})$ and protein $(\mathrm{g} / \mathrm{kg})$ was similar between the surgical and radiotherapy settings in both the HNC and EC groups (Table 5).

\subsection{Unplanned Admissions, Treatment Completion and Survival}

Rates of unplanned admission, treatment completion and survival were similar between EC and HNC groups. The unplanned admission rate was slightly higher for patients with EC than HNC (21/51 $(41 \%)$ versus $33 / 119(28 \%))$. The overall treatment completion rate was $139 / 170(82 \%)$ and was similar between EC and HNC groups (43/51 (84\%) versus 96/119 (81\%). At the end of the study, the overall proportion of patients surviving was 157/170 (92\%) with no difference between EC and HNC groups (45/51 (88\%) versus 112/119 (94\%).

\section{Discussion}

This is the first study to prospectively explore adherence to evidence-based nutrition care processes in an international multi-centre cohort of high-nutritional-risk patients with HNC and EC. By the adherence benchmarks described in our methods, the participating sites adhered well ( $>80 \%$ ) to recommendations for completing nutrition screening and assessment, perioperative nutrition assessment and nutrition prescription for energy and protein targets. Adherence was moderate ( $\geq 60$ to $<80 \%$ ) for utilizing validated screening and assessment tools and pre-radiotherapy dietitian consultation and poor $(<60 \%)$ for initiating post-operative nutrition support within $24 \mathrm{~h}$ and also dietetic consultation occurring weekly during radiotherapy and fortnightly for 6 weeks post-radiotherapy.

With regards to Quality Nutrition Care and Nutrition Monitoring and Evaluation, at a patient population or system level, the proportion of patients that received dietetic assessment from week to week ranged from $69 \%$ to $88 \%$ for patients with HNC and $41 \%$ to $74 \%$ for patients with EC. However, patient-level data revealed the evidence-based schedule of weekly dietitian consultations was adhered to for $42 \%$ of patients with HNC and $24 \%$ of patients with EC. This tapered further for the recommended fortnightly for six weeks post-treatment dietitian consultations to $13 \%$ and $17 \%$, respectively. Our patient-level data concur with the EBGs suggesting that weight loss and nutrition impact symptoms highlight the importance of ongoing access to nutrition care. Recommendations regarding perioperative nutrition assessment were largely well adhered to; however, nutrition intervention in terms of initiating post-operative nutrition support within $24 \mathrm{~h}$ was sub-optimal. Reasons for low adherence with some guideline recommendations were not captured within the scope of this study; however, given the tendency for variation in individual and institutional practices, exploration of local barriers and facilitators to improving EBG adherence within participating centres may be warranted.

The benefits of successful implementation of evidence-based nutrition care in line with best-practice in high-risk tumor groups are now well-documented. Australian-led implementation studies have demonstrated adherence to an evidence-based schedule of dietitian visits throughout treatment for HNC and recovery leads to improved outcomes for patients including nutritional status, weight maintenance, quality of life, treatment completion, and unplanned admissions [37,38,47]. Britton et al. [37,48] and McCarter et al. [47,49] uniquely demonstrated that dietitian-led delivery of motivational interviewing and cognitive behavioral therapy as part of an Eating as Treatment (EAT) intervention improved a range of patient outcomes. From a system-level perspective, Findlay et al. [38] demonstrated a $15 \%$ relative reduction in costly unplanned hospital admissions equating to (in Australian Dollars (AUD)) 14.65 AUD in costs avoided for every 1 AUD invested in delivering an evidence-based model of care to patients with HNC. Further, patients who required unplanned hospital admission due to their deteriorating condition utilized approximately twice the dietetics resources over the course of care with a median (range) number of dietitian consultations of 15 (3-66) versus 8 (2-29), $p<0.001$. 
Inadequate dietetic resources are frequently cited as a key barrier to delivering optimum nutrition care [33]; however, alongside medical and nursing expertise, allied health professionals are the third pillar of the health workforce [50] and, with the required upfront organizational investment, have the ability to deliver high value care.

Overcoming local barriers to guideline implementation, however, can be challenging and requires a multi-strategic approach. Martin et al. [36] have highlighted the need for standardized nutrition care pathways with clearly defined roles and responsibilities. Further, the prognostic significance of cancer-related malnutrition and sarcopenia [51-60] in these patients warrants specific attention. The Clinical Oncology Society of Australia (COSA) have recently articulated a Position Statement to support the implementation of a co-ordinated, multidisciplinary pathway for screening, assessment and treatment of these conditions [61]. A culture of review and audit is a longstanding mainstay of quality in healthcare and the availability of EBGs to guide cancer nutrition care represent an opportunity to establish this amongst cancer nutrition professionals as integral to overall quality in cancer care.

Our prospective audit was based on adherence criteria derived from the best-available evidence; however, EBGs are not without limitations, particularly when evidence quality is low or evidence gaps persist. As with all scientifically rigorous processes, the appropriateness of some EBG recommendations should be challenged. An example highlighted in our audit is the optimum nutrition prescription in terms of protein and energy targets. Different guidelines recommend a daily energy prescription of either $125 \mathrm{~kJ} / \mathrm{kg}$ (30 kcal/kg) [8,9] or 25-30 kcal/kg [12,14]; however, a recent study suggests that the lower end of this range ( $25 \mathrm{kcal} / \mathrm{kg} /$ day) specified in some EBGs may be insufficient to maintain positive energy balance and therefore ameliorate skeletal muscle depletion in patients with HNC [62]. Of note, the EFFORT trial (effect of early nutritional support on frailty, functional outcomes, and recovery of malnourished medical inpatients) implemented a systematic approach to individualized nutritional support in high-risk inpatients which demonstrated improved clinical outcomes, including survival [63]. However, it should also be acknowledged that merely increasing energy and protein targets is an overly simplistic view of what is frequently an enormously challenging aspect of self-managed care for ambulatory patients. Reasons for reduced nutritional intake are multifactorial and require multidisciplinary management to create a path to support patients to optimize nutrient intake. In an exploration of patient-reported barriers to following tube feeding prescription in patients with HNC despite intensive dietetic input, Brown et al. [64] concluded that understanding patient needs and optimizing multidisciplinary symptom management are vital to improving adherence to nutrition care recommendations. This prompts a call to action for high-quality research to fill known evidence gaps, and, as new findings to guide cancer nutrition care are published, EBGs and related recommendations subsequently require ongoing updates and should be accompanied by implementation guidance with clearly defined roles and responsibilities for multidisciplinary teams that also address patient-reported barriers.

Study strengths include the international perspective on adherence to evidence-based practice with a focus on tertiary referral centers that routinely manage high volumes of patients undergoing treatment for complex, high-nutritional risk cancers. In terms of limitations, the authors acknowledge the convenience sampling and lack of ethnic diversity in the study population may have resulted in selection bias. Despite the increasingly cultural and linguistic diversity of Western countries within which the study sites were located, the predominantly Caucasian study participants may be reflective of the challenges of recruiting cohorts that are representative of the broader population to research participation. Further, where data were reported at the system level, a truer reflection of sustained implementation of best-practice nutrition care processes may have been captured with whether adherence occurred at each nutrition intervention time point. Finally, the sample size was relatively small and the 11 participating sites may not be reflective of the practice at other sites. 


\section{Conclusions}

From an international perspective, adherence to evidence-based guideline recommendations in line with best-practice nutrition care of patients with HNC and EC was: good for baseline nutrition screening and assessment processes, perioperative nutrition assessment and nutrition prescription for energy and protein; moderate for utilizing validated screening and assessment tools and pre-radiotherapy dietitian consultation; and poor for initiating post-operative nutrition support within $24 \mathrm{~h}$, weekly dietetic consultation during radiotherapy and fortnightly for 6 weeks post-radiotherapy. This demonstrates there are still evidence to practice gaps in a global uptake of research evidence into practice for some aspects of care, highlighting areas for improvement. Where evidence-practice gaps persist, a systematic, multi-strategic approach that supports local implementation is required to better link research and practice in order to ultimately optimize patient care and outcomes.

Author Contributions: The authors' contributions were as follows: conceptualization, J.D.B., M.d.v.d.S., R.D., M.F., L.G., A.L., L.M.G. and A.W.; methodology, J.D.B., M.d.v.d.S., R.D., M.F., L.G., A.L., L.M.G. and A.W.; software, R.D. and L.G.; validation, R.D., L.G., L.M.; formal analysis, J.D.B., A.G.D., R.D., L.G., M.F., L.M.; investigation, J.B., M.d.v.d.S., R.D., M.F., L.M.G., A.L., L.M.G. and A.W.; resources, R.D. and L.M.G.; data curation, all authors; writing—original draft preparation, M.F.; writing—review and editing, all authors; visualization, M.F. and A.G.D.; supervision, L.M.G.; project administration, R.D. and L.M.G.; funding acquisition, R.D. and L.M.G. All authors have read and agreed to the published version of the manuscript.

Funding: The study was partially supported by funding from the Royal Alexandra Foundation and Fresenius Kabi. The funding bodies did not influence the study procedures or interpretation of results.

Acknowledgments: The authors acknowledge colleagues who provided support at each site as follows: Australia (Brisbane): Merrilyn Banks FDAA, Adrienne Young AdvAPD, Joanne Hiatt APD; Australia (Sydney): Gemma Collett BMedSc, Courtney Still, APD; Canada: Alberta Health Services, Nutrition Service in Calgary (Foothills Medical Center, Peter Lougheed Centre, Tom Baker Cancer Centre) and Edmonton (Cross Cancer Institute, Royal Alexandra Hospital and University of Alberta Hospital); Italy (Rome): Alessia Fallarino MD; Netherlands (Amsterdam) Loes van Aken RD; Simone Eerenstein MD, Donald van der Peet MD; USA (Sacramento): Kathleen Newman RDN CSO, Michelle Chellino MS, and Fiona Young MS RDN.

Conflicts of Interest: The listed authors wish to make the following disclosures: Leah Gramlich received an investigator initiated grant from Fresenius Kabi Deutchland and an educational grant from Baxter during the conduct of the study. Rupinder Dhaliwal reports travel support for investigator meeting from Nestle Health Science Canada and personal fees from Alberta Health Services during the conduct of the study. Alessandro Laviano reports personal fees from Abbott, personal fees from Baxter, personal fees from BBraun, personal fees from Fresenius-Kabi, personal fees from Nestlé Health Science and personal fees from Nutricia outside the submitted work. Andrew Day received funding from Alberta Heath Services for statistical consulting. The remaining authors declare no conflict of interest.

\section{References}

1. van Bokhorst-de van der Schueren, M.A.; van Leeuwen, P.A.; Kuik, D.J.; Klop, W.M.; Sauerwein, H.P.; Snow, G.B.; Quak, J.J. The impact of nutritional status on the prognoses of patients with advanced head and neck cancer. Cancer 1999, 86, 519-527. [CrossRef]

2. Riccardi, D.; Allen, K. Nutritional Management of Patients With Esophageal and Esophagogastric Junction Cancer. Cancer Control. 1999, 6, 64-72. [CrossRef] [PubMed]

3. Hébuterne, X.; Lemarié, E.; Michallet, M.; De Montreuil, C.B.; Schneider, S.M.; Goldwasser, F. Prevalence of Malnutrition and Current Use of Nutrition Support in Patients With Cancer. J. Parenter. Enter. Nutr. 2014, 38, 196-204. [CrossRef] [PubMed]

4. Arends, J.; Baracos, V.; Bertz, H.; Bozzetti, F.; Calder, P.C.; Deutz, N.E.P.; Erickson, N.; Laviano, A.; Lisanti, M.P.; Lobo, D.N.; et al. ESPEN expert group recommendations for action against cancer-related malnutrition. Clin. Nutr. 2017, 36, 1187-1196. [CrossRef]

5. Van Cutsem, E.; Arends, J. The causes and consequences of cancer-associated malnutrition. Eur. J. Oncol. Nurs. 2005, 9, S51-S63. [CrossRef]

6. Baracos, V.E. Cancer-associated malnutrition. Eur. J. Clin. Nutr. 2018, 72, 1255-1259. [CrossRef]

7. Baracos, V.E.; Martin, L.; Korc, M.; Guttridge, D.C.; Fearon, K.C.H. Nature Reviews Disease Primers. Nat. Rev. Dis. Prim. 2019, 4, 17105. [CrossRef] 
8. Findlay, M.; Bauer, J.; Brown, T.; Davidson, W.; Isenring, E.; Kiss, N.; Kurmis, R.; Loeliger, J.; Sandison, A.; Talwar, B.; et al. Evidence-Based Practice Guidelines for the Nutritional Management of Adult Patients with Head and Neck Cancer; Cancer Council Australia: Sydney, Australia, 2009; Available online: http://wiki.cancer.org. au/australia/COSA:Head_and_neck_cancer_nutrition_guidelines (accessed on 4 June 2019).

9. Isenring, E.A.; Zabel, R.; Bannister, M.; Brown, T.; Findlay, M.; Kiss, N.; Loeliger, J.; Johnstone, C.; Camilleri, B.; Davidson, W.; et al. Updated evidence-based practice guidelines for the nutritional management of patients receiving radiation therapy and/or chemotherapy. Nutr. Diet. 2013, 70, 312-324. [CrossRef]

10. Dort, J.C.; Farwell, D.; Findlay, M.; Gerhard, F.H.; Paul, K.; Melissa, A.S.-B.; Christian, S.; Jeffrey, U.; David, Z.; Olle, L. Optimal perioperative care in major head and neck cancer surgery with free flap reconstruction: A consensus review and recommendations from the enhanced recovery after surgery society. JAMA Otolaryngol. Head Neck Surg. 2017, 143, 292-303. [CrossRef]

11. Weimann, A.; Braga, M.; Carli, F.; Higashiguchi, T.T.; Hübner, M.; Klek, S.; Laviano, A.; Ljungqvist, O.; Lobo, D.N.; Martindale, R.; et al. ESPEN guideline: Clinical nutrition in surgery. Clin. Nutr. 2017, 36, 623-650. [CrossRef]

12. Pertkiewicz, M.; Ljungqvist, O.; Soeters, P.; Fearon, K.; Weimann, A.; Bozzetti, F. ESPEN Guidelines on Parenteral Nutrition: Surgery. Clin. Nutr. 2009, 28, 378-386. [CrossRef]

13. Weimann, A.; Braga, M.; Harsanyi, L.; Laviano, A.; Ljungqvist, O.; Soeters, P.; Jauch, K.; Kemen, M.; Hiesmayr, J.; Horbach, T.; et al. ESPEN Guidelines on Enteral Nutrition: Surgery including Organ Transplantation. Clin. Nutr. 2006, 25, 224-244. [CrossRef] [PubMed]

14. Arends, J.; Bachmann, P.; Baracos, V.; Barthelemy, N.; Bertz, H.; Bozzetti, F.; Fearon, K.; Hutterer, E.; Isenring, E.; Kaasa, S.; et al. ESPEN guidelines on nutrition in cancer patients. Clin. Nutr. 2017, 36, 11-48.

15. Thompson, K.L.; Elliott, L.; Fuchs-Tarlovsky, V.; Levin, R.M.; Voss, A.C.; Piemonte, T. Oncology Evidence-Based Nutrition Practice Guideline for Adults. J. Acad. Nutr. Diet. 2017, 117, 297-310.e47. [CrossRef] [PubMed]

16. Talwar, B.; Donnelly, R.; Skelly, R.; Donaldson, M. Nutritional management in head and neck cancer: United Kingdom National Multidisciplinary Guidelines. J. Laryngol. Otol. 2016, 130, S32-S40. [CrossRef] [PubMed]

17. Guyatt, G.; Oxman, A.D.; Akl, E.A.; Kunz, R.; Vist, G.; Brozek, J.; Norris, S.; Falck-Ytter, Y.; Glasziou, P.; DeBeer, H.; et al. GRADE guidelines: 1 . Introduction-GRADE evidence profiles and summary of findings tables. J. Clin. Epidemiol. 2011, 64, 383-394. [CrossRef]

18. Handu, D.; Moloney, L.; Wolfram, T.; Ziegler, P.; Acosta, A.; Steiber, A. Academy of Nutrition and Dietetics Methodology for Conducting Systematic Reviews for the Evidence Analysis Library. J. Acad. Nutr. Diet. 2016, 116, 311-318. [CrossRef]

19. Scottish Intercollegiate Guidelines Network. A Guideline Developer's Handbook; SIGN: Edinburgh, UK, 2014; Available online: http://www.sign.ac.uk (accessed on 19 September 2020).

20. National Health and and Medical Research Council. NHMRC levels of evidence and grades for recommendations for guideline developers. In NHMRC Levels of Evidence and Grades for Recommendations; National Health and and Medical Research Council: Sydney, Australia, 2009.

21. Schütz, T.; Herbst, B.; Koller, M. Methodology for the development of the ESPEN Guidelines on Enteral Nutrition. Clin. Nutr. 2006, 25, 203-209. [CrossRef]

22. Bero, L.A.; Grilli, R.; Grimshaw, J.M.; Harvey, E.; Oxman, A.D.; Thomson, M.A. Getting research findings into practice: Closing the gap between research and practice: An overview of systematic reviews of interventions to promote the implementation of research findings. BMJ 1998, 317, 465-468. [CrossRef]

23. Green, L.W.; Ottoson, J.M.; García, C.; Hiatt, R.A. Protected], [Email Diffusion Theory and Knowledge Dissemination, Utilization, and Integration in Public Health. Annu. Rev. Public Health 2009, 30, 151-174. [CrossRef]

24. Balas, E.; Weingarten, S.; Garb, C.T.; Blumenthal, D.; A Boren, S.; Brown, G.D. Improving preventive care by prompting physicians. Arch. Intern. Med. 2000, 160, 301-308. [CrossRef]

25. Balas, E.B.S. Managing clinical knowledge for health care improvement. In Yearbook of Medical Informatics 2000: Patient-Centered Systems; Bemmel, J.M.A., Ed.; Schattauer Verlagsgesellschaft mbH: Stuttgart, Germany, 2000; pp. 65-70.

26. Grimshaw, J.; Eccles, M.; Tetroe, J. Implementing clinical guidelines: Current evidence and future implications. J. Contin. Educ. Health Prof. 2004, 24, S31-S37. [CrossRef] [PubMed] 
27. Hakel-Smith, N.; Lewis, N.M. A standardized nutrition care process and language are essential components of a conceptual model to guide and document nutrition care and patient outcomes. J. Am. Diet. Assoc. 2004, 104, 1878-1884. [CrossRef] [PubMed]

28. Lacey, K.; Pritchett, E. Nutrition Care Process and Model: ADA adopts road map to quality care and outcomes management. J. Am. Diet. Assoc. 2003, 103, 1061-1072. [CrossRef]

29. Detsky, A.S.; McLaughlin, J.R.; Baker, J.P.; Johnston, N.; Whittaker, S.; A Mendelson, R.; Jeejeebhoy, K.N. What is subjective global assessment of nutritional status? J. Parenter. Enter. Nutr. 1987, 11, 8-13. [CrossRef] [PubMed]

30. Ottery, F.D. Patient generated-subjective global assessment. In The Clinical Guide to Oncology Nutrition; McCallum, P., Polisena, C., Eds.; The American Dietetic Association: Chicago, CA, USA, 2000; pp. 11-23.

31. Jager-Wittenaar, H.; Ottery, F.D. Assessing nutritional status in cancer: Role of the Patient-Generated Subjective Global Assessment. Curr. Opin. Clin. Nutr. Metab. Care 2017, 20, 322-329. [CrossRef] [PubMed]

32. Food and Nutrition Board; Health and Medicine Division; National Academies of Sciences, Engineer and Medicine. Examining Access to Nutrition Care in Outpatient Cancer Centers: Proceedings of a Workshop; The National Academies of Sciences, Engineering and Medicine: Washington, DC, USA, 2016.

33. Brown, T.; Findlay, M. Current issues in the nutritional management of patients with head and neck cancer in Australia. Cancer Forum 2011, 35, 92-96.

34. Trujillo, E.B.; Dixon, S.W.; Claghorn, K.; Levin, R.M.; Mills, J.B.; Spees, C.K. Closing the Gap in Nutrition Care at Outpatient Cancer Centers: Ongoing Initiatives of the Oncology Nutrition Dietetic Practice Group. J. Acad. Nutr. Diet. 2018, 118, 749-760. [CrossRef] [PubMed]

35. Smith, T.J.; Hillner, B.E. Ensuring quality cancer care by the use of clinical practice guidelines and critical pathways. J. Clin. Oncol. 2001, 19, 2886-2897. [CrossRef]

36. Martin, L.; de van der Schueren, M.A.E.; Blauwhoff-Buskermolen, S.; Baracos, V.; Gramlich, L. Identifying the Barriers and Enablers to Nutrition Care in Head and Neck and Esophageal Cancers. J. Parenter. Enter. Nutr. 2014, 40, 355-366. [CrossRef]

37. Britton, B.; Baker, A.L.; Wolfenden, L.; Wratten, C.; Bauer, J.; Beck, A.K.; McCarter, K.; Harrowfield, J.; Isenring, E.; Tang, C.; et al. Eating As Treatment (EAT): A Stepped-Wedge, Randomized Controlled Trial of a Health Behavior Change Intervention Provided by Dietitians to Improve Nutrition in Patients With Head and Neck Cancer Undergoing Radiation Therapy (TROG 12.03). Int. J. Radiat. Oncol. 2019, 103, 353-362. [CrossRef]

38. Findlay, M.; Rankin, N.M.; Shaw, T.; White, K.; Boyer, M.; Milross, C.G.; Lourenço, R.D.A.; Brown, C.; Collett, G.; Beale, P.; et al. Best Evidence to Best Practice: Implementing an Innovative Model of Nutrition Care for Patients with Head and Neck Cancer Improves Outcomes. Nutrients 2020, 12, 1465. [CrossRef] [PubMed]

39. Oken, M.M.; Creech, R.H.; Tormey, D.C.; Horton, J.; Davis, T.E.; McFadden, E.T.; Carbone, P.P. Toxicity and response criteria of the Eastern Cooperative Oncology Group. Am. J. Clin. Oncol. 1982, 5, 649-656. [CrossRef] [PubMed]

40. Ferguson, M.; Capra, S.; Bauer, J.; Banks, M. Development of a valid and reliable malnutrition screening tool for adult acute hospital patients. Nutrients 1999, 15, 458-464. [CrossRef]

41. Kondrup, J.; Rasmussen, H.H.; Hamberg, O.; Stanga, Z. Nutritional risk screening (NRS 2002): A new method based on an analysis of controlled clinical trials. Clin. Nutr. 2003, 22, 321-336. [CrossRef]

42. Rubenstein, L.Z.; Harker, J.O.; Salvà, A.; Guigoz, Y.; Vellas, B. Screening for Undernutrition in Geriatric Practice: Developing the Short-Form Mini-Nutritional Assessment (MNA-SF). J. Gerontol. Ser. A Boil. Sci. Med. Sci. 2001, 56, M366-M372. [CrossRef]

43. Kruizenga, H.M.; Seidell, J.; De Vet, H.C.W.; Wierdsma, N.; Schueren, M.A.E.V.B.-D.V.D. Development and validation of a hospital screening tool for malnutrition: The short nutritional assessment questionnaire (SNAQ $\left.{ }^{(}\right)$. Clin. Nutr. 2005, 24, 75-82. [CrossRef]

44. American Dietetic Association. Nutrition Diagnosis and Intervention: Standardized Language for the Nutrition Care Process.; American Dietetic Association: Chicago, IL, USA, 2007.

45. Harris, P.A.; Taylor, R.; Thielke, R.; Payne, J.; Gonzalez, N.; Conde, J.G. Research electronic data capture (REDCap)-A metadata-driven methodology and workflow process for providing translational research informatics support. J. Biomed. Inform. 2009, 42, 377-381. [CrossRef] 
46. Von Elm, E.; Altman, D.G.; Egger, M.; Pocock, S.J.; Gotzsche, P.C.; Vandenbroucke, J.P. The Strengthening the Reporting of Observational Studies in Epidemiology (STROBE) statement: Guidelines for reporting observational studies. J. Clin. Epidemiol. 2008, 61, 344-349. [CrossRef]

47. McCarter, K.L.; Baker, A.L.; Britton, B.; Halpin, S.A.; Beck, A.; Carter, G.; Wratten, C.; Bauer, J.; Wolfenden, L.; Burchell, K.; et al. Head and neck cancer patient experience of a new dietitian-delivered health behaviour intervention: 'You know you have to eat to survive'. Support. Care Cancer 2018, 26, 2167-2175. [CrossRef]

48. Britton, B.; McCarter, K.; Baker, A.; Wolfenden, L.; Wratten, C.; Bauer, J.; Beck, A.; McElduff, P.; Halpin, S.; Carter, G. Eating As Treatment (EAT) study protocol: A stepped-wedge, randomised controlled trial of a health behaviour change intervention provided by dietitians to improve nutrition in patients with head and neck cancer undergoing radiotherapy. BMJ Open 2015, 5, e008921. [CrossRef]

49. McCarter, K.; Baker, A.L.; Britton, B.; Beck, A.K.; Carter, G.; Bauer, J.; Wratten, C.; A Halpin, S.; Holliday, E.; Oldmeadow, C.; et al. Effectiveness of clinical practice change strategies in improving dietitian care for head and neck cancer patients according to evidence-based clinical guidelines: A stepped-wedge, randomized controlled trial. Transl. Behav. Med. 2018, 8, 166-174. [CrossRef] [PubMed]

50. Edelstein, P. Navigating Healthcare Reform-E-Book: An Insider's Guide for Nurses and Allied Health Professionals, 1st ed.; Elselvier: Amsterdam, The Netherlands, 2017; p. 283.

51. Findlay, M.; White, K.; Lai, M.; Luo, D.; Bauer, J.D. The Association Between Computed Tomography-Defined Sarcopenia and Outcomes in Adult Patients Undergoing Radiotherapy of Curative Intent for Head and Neck Cancer: A Systematic Review. J. Acad. Nutr. Diet. 2020, 120, 1330-1347.e8. [CrossRef] [PubMed]

52. Findlay, M.; Brown, C.; Lourenço, R.D.A.; White, K.; Bauer, J. Sarcopenia and myosteatosis in patients undergoing curative radiotherapy for head and neck cancer: Impact on survival, treatment completion, hospital admission and cost. J. Hum. Nutr. Diet. 2020, 33, 811-821. [CrossRef] [PubMed]

53. Hua, X.; Liu, S.; Liao, J.-F.; Wen, W.; Long, Z.-Q.; Lu, Z.-J.; Guo, L.; Lin, H.-X. When the Loss Costs Too Much: A Systematic Review and Meta-Analysis of Sarcopenia in Head and Neck Cancer. Front. Oncol. 2020, 9, 1561. [CrossRef] [PubMed]

54. Kubrak, C.; Martin, L.; Gramlich, L.; Scrimger, R.; Jha, N.; Debenham, B.; Chua, N.; Walker, J.; Baracos, V.E. Prevalence and prognostic significance of malnutrition in patients with cancers of the head and neck. Clin. Nutr. 2020, 39, 901-909. [CrossRef]

55. Martin, L.; Gioulbasanis, I.; Senesse, P.; Baracos, V.E. Cancer-Associated Malnutrition and CT-Defined Sarcopenia and Myosteatosis Are Endemic in Overweight and Obese Patients. J. Parenter. Enter. Nutr. 2020, 44, 227-238. [CrossRef]

56. Sealy, M.J.; Dechaphunkul, T.; van der Schans, C.P.; Krijnen, W.P.; Roodenburg, J.L.N.; Walker, J.; Jager-Wittenaar, H.; Baracos, V.E. Low muscle mass is associated with early termination of chemotherapy related to toxicity in patients with head and neck cancer. Clin. Nutr. 2020, 39, 501-509. [CrossRef]

57. Wong, A.; Zhu, D.; Kraus, D.; Tham, T. Radiologically Defined Sarcopenia Affects Survival in Head and Neck Cancer: A Meta-Analysis. Laryngoscope 2020. [CrossRef]

58. Saeed, S.D.; Fontaine, J.; Pena, L.; Hoffe, S.E.; Frakes, J.; Metha, R.; Gurd, E.; Pimiento, J.M. Prognostic value of nutritional status for esophageal cancer patients undergoing neoadjuvant therapy and resection. J. Clin. Oncol. 2019, 37, 133. [CrossRef]

59. Simonsen, C.; de Heer, P.; Bjerre, E.D.; Suetta, C.; Hojman, P.; Pedersen, B.K.; Svendsen, L.B.; Christensen, J.F. Sarcopenia and Postoperative Complication Risk in Gastrointestinal Surgical Oncology: A Meta-analysis. Ann. Surg. 2018, 268, 58-69. [CrossRef]

60. Shachar, S.S.; Williams, G.R.; Muss, H.B.; Nishijima, T.F. Prognostic value of sarcopenia in adults with solid tumours: A meta-analysis and systematic review. Eur. J. Cancer 2016, 57, 58-67. [CrossRef] [PubMed]

61. Kiss, N.; Loeliger, J.; Findlay, M.; Isenring, E.; Baguley, B.J.; Boltong, A.; Butler, A.; Deftereos, I.; Eisenhuth, M.; Fraser, S.F.; et al. Clinical Oncology Society of Australia: Position statement on cancer-related malnutrition and sarcopenia. Nutr. Diet. 2020, 77, 416-425. [CrossRef]

62. McCurdy, B.; Nejatinamini, S.; Debenham, B.; Álvarez-Camacho, M.; Kubrak, C.; Wismer, W.V.; Mazurak, V. Meeting Minimum ESPEN Energy Recommendations Is Not Enough to Maintain Muscle Mass in Head and Neck Cancer Patients. Nutrients 2019, 11, 2743. [CrossRef] [PubMed]

63. Schuetz, P.; Fehr, R.; Baechli, V.; Geiser, M.; Deiss, M.; Gomes, F.; Kutz, A.; Tribolet, P.; Bregenzer, T.; Braun, N.; et al. Individualised nutritional support in medical inpatients at nutritional risk: A randomised clinical trial. Lancet 2019, 393, 2312-2321. [CrossRef] 
64. Brown, T.E.; Banks, M.; Hughes, B.G.; Lin, C.; Kenny, L.; Bauer, J. Tube feeding during treatment for head and neck cancer-Adherence and patient reported barriers. Oral Oncol. 2017, 72, 140-149. [CrossRef]

Publisher's Note: MDPI stays neutral with regard to jurisdictional claims in published maps and institutional affiliations.

(C) 2020 by the authors. Licensee MDPI, Basel, Switzerland. This article is an open access article distributed under the terms and conditions of the Creative Commons Attribution (CC BY) license (http://creativecommons.org/licenses/by/4.0/). 